\title{
Rasch Model untuk Memvalidasi Instrumen Resiliensi Matematis Mahasiswa Calon Guru Matematika
}

\author{
Muntazhimah $^{\left.1^{*}\right)}$, Syifani Putri ${ }^{2}$, \& Hikmatul Khusna ${ }^{3}$ \\ 1, 2, ${ }^{3}$ Universitas Muhammadiyah Prof. Dr. Hamka, Jakarta, Indonesia
}

\section{INFO ARTICLES}

Article History:

Received: 07-12-2020

Revised: 20-12-2020

Approved: 21-12-2020

Publish Online: 25-12-2020

Key Words:
The Rasch Model; The
Mathematical Resilience
Instrument; Validity;

\begin{abstract}
This study aims to examine the reliability and validity of the instruments of mathematical resilience of mathematics teacher students' candidates using Rasch model. Mathematical resilience in this study has four indicators which are derived into thirty-two statement items. The number of respondents in this study were 126 people who were selected by using purposive sampling technique. The result of the data analysis shows that mathematical resilience instrument of mathematics teacher students' candidates is declared reliable and valid with the criteria "very reliable" and 29 out of 32 items of statements are said to be "valid". Furthermore, to examine the mathematical resilience ability of mathematics teacher students' candidates can be measured using this instrument.
\end{abstract}

\begin{abstract}
Abstrak: Penelitian ini bertujuan untuk mengkaji reliabilitas dan validitas instrumen kemampuan resiliensi matematis mahasiswa calon guru matematika dengan memakai model Rasch. Resiliensi matematis pada penelitian ini memiliki empat indikator yang diturunkan menjadi tiga puluh dua item pernyataan. Responden pada penelitian ini berjumlah 126 orang yang dipilih dengan cara purposive sampling. Hasil analisis datanya menunjukkan bahwa instrumen kemampuan resiliensi matematis mahasiswa calon guru matematika dinyatakan reliabel dan valid dengan kriteria "sangat reliabel" dan 29 dari 32 item pernyataan dikatakan "valid", sehingga untuk meneliti kemampuan resiliensi matematis mahasiswa calon guru matematika bisa diukur dengan menggunakan instrumen ini.
\end{abstract}

\section{Correspondence Address: Jln. FKIP UHAMKA JL. $\quad$ Tanah merdeka. Ciracas. Jaktim e-mail:} muntazhimah@uhamka.ac.id

How to Cite (APA $6^{\text {th }}$ Style): Muntazhimah, M., Putri, S., \& Khusna, H. (2020). Rasch Model untuk Memvalidasi Instrumen Resiliensi Matematis Mahasiswa Calon Guru Matematika. JKPM (Jurnal Kajian Pendidikan Matematika), 6(1): $65-74$.

Copyright: 2020 Muntazhimah Muntazhimah, Syifani Putri, Hikmatul Khusna

Competing Interests Disclosures: The authors declare that they have no significant competing financial, professional or personal interests that might have influenced the performance or presentation of the work described in this manuscript. 


\section{PENDAHULUAN}

Undang-Undang Nomor 20 Tahun 2003 tentang Sistem Pendidikan Nasional mengamanatkan bahwa matematika adalah salah satu mata pelajaran wajib dalam pendidikan formal mulai dari sekolah dasar sampai sekolah menengah (Kemdikbud, 2016). Dengan adanya amanat tersebut maka setiap siswa akan mengalami belajar matematika selama bersekolah kurang lebih lima belas tahun dalam hidupnya. Organisation for Economic Co-operation and Development (OECD) menyebutkan bahwa kebanyakan populasi dalam suatu negara didunia merasakan perasaan negatif ketika mempelajari matematika (Xolocotzin, 2017). Contoh dari perasaan negatif tersebut misalnya beberapa siswa merasa sangat kurang percaya diri ketika dihadapkan dengan pembelajaran matematika, bahkan merasa frustasi, tidak memahami dan merasa bodoh terhadap langkah penyelesaian yang harus dilakukan (Johnston-Wilder et. al., 2015). Berbagai macam sikap yang dilakukan siswa ketika menghadapi tantangan-tantangan dalam pembelajaran matematikapun berbeda-beda, ada yang dapat mengatasi dengan keadaan yang baik namun tidak jarang pula ada yang belum mampu mengatasi tantangan dalam pembelajaran matematika bahkan memilih untuk menghindari tantangan tersebut (Johnston-Wilder, 2013). Sikap individu yang mampu beradaptasi, kuat dan tangguh menghadapi tantangan, tetap teguh, optimis dan positif dengan kemampuan dirinya untuk dapat mengatasi tantangan tersebut dapat dikatakan dengan sikap resiliensi (Hendriana et al., 2017); (Hutauruk, 2020); (JohnstonWilder et. al., 2015).

Sikap, kepribadian dan karakter termasuk merupakan fenomena kualitatif yang bersifat latent (tidak bisa diamati secara langsung), dan melakukan pembobotannya secara kuantitatif dalam ilmu sosial termasuk didalamnya pendidikan, adalah suatu kesulitan yang mendasar (Cavanagh \& Waugh, 2011). Pendekatan yang masih banyak dipakai untuk melakukan penilaian dalam dunia pendidikan adalah melalui teori tes klasik atau CTT (clasical test theory) (Sumintono, 2016). Asumsi dasar dari CTT adalah bahwa hasil penjumlahan antara skor murni (T) dan error (E) akan menghasilkan skor tampak (X) yang berarti bahwa dalam skor hasil ujian yang diperoleh seorang siswa, di dalamnya terdiri dari skor murni dan error. Error merupakan segala kondisi situasional yang bersifat latent. Jelas bahwa CTT hanya menekankan pada skor tampak dari satu ujian, yang biasanya disimpulkan sebagai kemampuan (abilitas) seseorang dari ujian yang diikuti. Hal ini kurang relevan karena skor yang dihasilkan dari suatu item tersebut bersifat ordinal sehingga tidak dapat diperlakukan sebagaimana bilangan bulat (Wibisono, 2018).

Model Rasch melakukan pengembangan alat ukur pada ilmu sosial merupakan respon atas berbagai kelemahan paradigma CTT (Sumintono, Bambang \& Widhiarso, 2015). Perbedaan mendasar model Rasch jika dibandingkan CTT antara lain terletak pada bagaimana memperlakukan skor mentah dalam proses analisis. Dalam CTT, skor mentah dalam bentuk peringkat (rating scale) langsung dianalisis dan diperlakukan sebagai data yang seolah-olah memiliki karakter bilangan bulat. Sedangkan dalam model Rasch, data mentah tidak dapat langsung dianalisis, melainkan harus dikonversikan dulu ke dalam bentuk 'odds ratio' untuk kemudian dilakukan transformasi logaritma menjadi unit logit sebagai manifestasi probabilitas responden dalam merespon suatu item (Wibisono, 2018). Mengacu pada prosedur ini, maka model Rasch dapat dijadikan sebagai metode dalam mengembalikan data sesuai kondisi alamiahnya (Sumintono \& Widhiarso, 2013). Kondisi alamiah ini mengacu pada karakteristik dasar data kuantitatif, yaitu bersifat kontinum. Melalui model Rasch, sebuah respon yang bersifat ordinal dapat ditransformasikan ke dalam bentuk rasio yang memiliki tingkat akurasi lebih tinggi dengan mengacu pada prinsip probabilitas. Hal yang membedakan antara model Rasch dengan CTT adalah bahwa dalam analisis data dengan model Rasch, data menyesuaikan model, sedangkan dalam CTT, model dipilih berbasis pada data. Berdasarkan hal ini, penggunaan model Rasch dalam validasi instrumen ini akan menghasilkan informasi yang lebih holistik tentang instrumen dan lebih memenuhi definisi pengukuran. 
Di Indonesia, penelitian terkait dengan resiliensi matematis masih tergolong topik baru, walaupun sudah ada beberapa yang melakukan penelitian di sekolah dasar dan menengah maupun perguruan tinggi, namun jumlahnya belum signifikan dan masih harus terus dilakukan penelitiannya. Hal ini selaras dengan pengembangan instrumennya, padahal fungsi instrumen pada kegiatan evaluasi dalam dunia pendidikan, adalah untuk memperoleh hasil yang lebih baik sesuai dengan kenyataan yang dievaluasi atau diteliti (Sappaile, 2007). Maka instrumen evaluasi dalam sebuah penelitian dalam bidang pendidikan harus dibuat menjadi alat pengukur yang baik dan berkualitas, sehingga dapat menghasilkan nilai yang objektif dan akurat (Muntazhimah, 2019). Penelitian ini bertujuan untuk mengkaji reliabilitas dan validitas instrumen kemampuan resiliensi matematis mahasiswa calon guru matematika dengan memakai model Rasch. Rasch model dijalankan melalui program winsteps, yang mana program ini adalah program khusus untuk Rasch model yang dapat berkerja pada sistem Microsoft Windows yang dibuat oleh John Linacre.

\section{METODE}

Responden penelitian ini berjumlah 126 mahasiswa program studi pendidikan matematika yang dipilih menggunakan metode purposive sampling, pertimbangannya adalah dikarenakan kondisi pandemi dan keterbatasan waktu dan sumber daya agar penelitian lebih cepat dan lebih efisien pelaksanaannya, tidak ada paksaan atau konsekuensi apapun yang akan diterima oleh responden dalam keterlibatannya di penelitian ini. Kemampuan resiliensi matematis mahasiswa calon guru matematika diwakili oleh empat buah indikator dan setiap indikator akan diturunkan dalam tujuh hingga sembilan pernyataan baik pernyataan positif maupun negatif. Secara rinci, kaitan antara indikator dan item pernyataan bisa dilihat pada Tabel 1.

Tabel 1. Kisi-Kisi Instrumen Resiliensi Matematis Calon Guru Matematika

\begin{tabular}{lcccc}
\hline Indikator & No. Item & Positif & Negatif & Banyak Butir \\
\hline $\begin{array}{l}\text { Memiliki keyakinan bahwa matematika } \\
\text { sebagai sesuatu yang berharga dan layak }\end{array}$ & 6789 & 1345 & 2 & 9 \\
untuk ditekuni dan dipelajari. & & & & \\
Memiliki kemauan dan kegigihan dalam & 101112 & 111316 & 101214 & 8 \\
mempelajari matematika, walaupun & 131415 & 17 & 15 & \\
mengalami kesulitan, hambatan dan & 1617 & & & \\
tantangan. & & & & \\
Memiliki keyakinan pada diri sendiri mampu & 181920 & 181920 & 212224 & \\
mempelajari dan menguasai matematika, & 212223 & 23 & & \\
baik berdasarkan pemahaman atas & 24 & & & \\
matematika, kemampuan menciptakan & & & & \\
strategi, bantuan alat dan orang lain, dan juga \\
pengalaman yang dibangun.
\end{tabular}

Penelitian ini dianalisis dengan menggunakan model Rasch karena mampu melihat interaksi antara responden dan item sekaligus. Dalam model Rasch, sebuah nilai tidak dilihat berdasarkan skor mentah, melainkan nilai logit yang mencerminkan probabilitas keterpilihan suatu item pada sekelompok responden. Hal ini digunakan sebagai antisipasi skor mentah dari rating Likert yang berbentuk ordinal yang tidak 
memiliki kesamaan interval antar skornya. Penggunaan model Rasch untuk data politomi dikembangkan oleh Andrich dengan tetap berlandaskan pada dua teorema dasar, yakni tingkat kemampuan/kesetujuan individu dan tingkat kesulitan item untuk disetujui (Misbach \& Sumintono, 2014). Output yang dipakai untuk analisis data adalah output summary statistics (Gambar 1.) untuk mendapatkan informasi reliabilitas serta output item undimensionality (Gambar 2.) dan Item Fit Order (Gambar 3.) untuk validitas.

\section{HASIL}

Hasil pengolahan data berupa output berbentuk gambar yang diperoleh dari software Winstep Rasch 4.4.3 yang dimiliki lisensinya oleh peneliti untuk melihat reliabilitas dan validitas instrumen resiliensi matematis.

1. Reliabilitas instrumen

Reliabilitas instrumen dilakukan untuk melihat apakah instrumen kemampuan resiliensi matematis ini reliabel, bisa digunakan sebagai alat ukur untuk mengukur resiliensi matematis calon guru matematika kapanpun dan dimanapun digunakan. Untuk melihat reliabilitas instrumen yang akan diuji, maka digunakanlah Summary statistic (lihat Gambar 1.) di program Winsteps. Salah satu informasi yang dapat di interpretasikan melalui output Summary Statistics ini, yaitu menampilkan nilai untuk pengukuran reliabilitas, baik pengukuran dari sisi responden (person reliability) ataupun dari tinjauan item pertanyaan (item reliability) serta interaksi antara responden dengan item. Berikut adalah gambar dari Output Summary Statistics (3.1) yang menujukkan informasi reliabilitas instrumen yang digunakan:

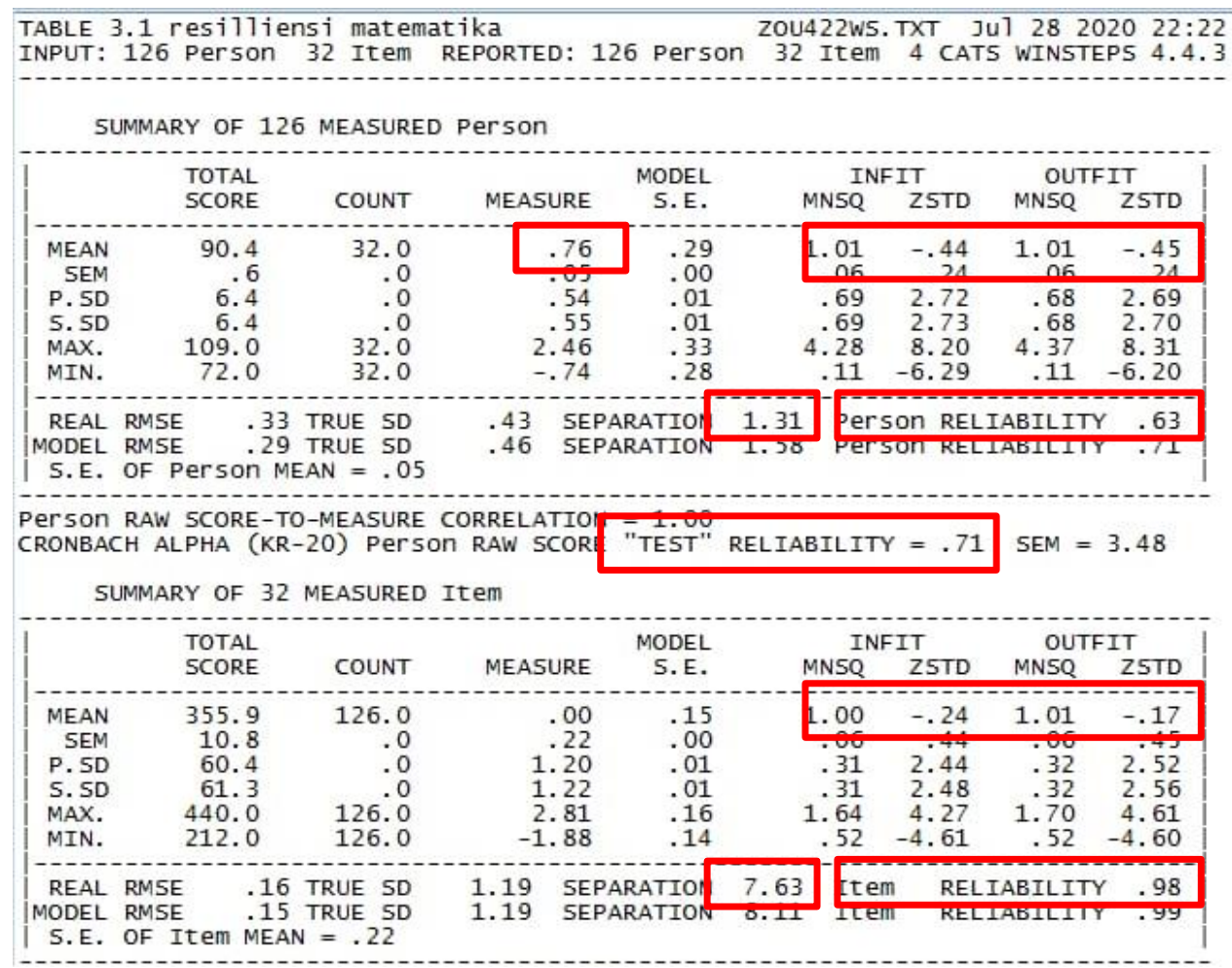

\section{Gambar 1. Output Summary Statistics pada Winstep}

Melalui output dari tabel Summary Statistics tersebut, akan memberikan informasi bagaimana kualitas instrumen (item) dan responden (person) dalam menjawab, serta terlihat juga interaksi antara person dan item sekaligus. Sehingga yang perlu untuk kita bahas dari Gambar 1. ini adalah Person 
measure untuk menunjukkan rata-rata nilai responden dalam instrumen dilihat dari mean measure skornya 0,76 . Nilai alpha cronbach yang merupakan tolak ukur reliabilitas yaitu interaksi antara person dan item sekaligus diperoleh dari skor "Test" reliability yaitu 0,71 . Nilai person reliability untuk melihat konsistensi jawaban dari responden yaitu 0,63 , dan item reliability yang merupakan nilai reliabilitas butir soal untuk mengetahui kualitas item-item dalam instrumen tersebut yaitu 0,98, Serta INFIT dan OUTFIT $M N S Q$ dan ZSTD, dan tidak ketinggalan separationnya.

2. Validitas instrumen

Validitas intrumen digunakan untuk menguji apakah instrumen kemampuan resiliensi matematis mahasiswa calon guru matematika ini memang bisa digunakan untuk mengukur kemampuan resiliensi matematis mahasiswa calon guru matematika. Bagian ini merupakan langkah untuk mengetahui kerangka umum dari fungsi matematika yang secara khusus menjelaskan mengenai interaksi antara subjek (person) dengan butir skala/item (test items). Tabel yang digunakan dalam software Winstep adalah tabel 23 (lihat Gambar 2.) dan tabel 10 (lihat Gambar 3.) yaitu Item undimensionality dan Item Fit Order. Outputnya akan menampilkan kegunaan untuk menguji item instrumen, yaitu item instrumen mana yang tepat untuk mengukur apa yang seharusnya diukur. Analisis validitas instrumen resiliensi matematis ini dalam program Winsteps disebut dengan uji fit dan misfit (item yang valid dan tidak valid). Kriteria yang digunakan untuk memeriksa item tersebut termasuk fit atau misfit dapat dilakukan dengan menganalisis output dari Item fit order ini, Berikut adalah gambar dari output dari kedua tabel tersebut yang menujukkan informasi kriteria validitas instrument yang digunakan:

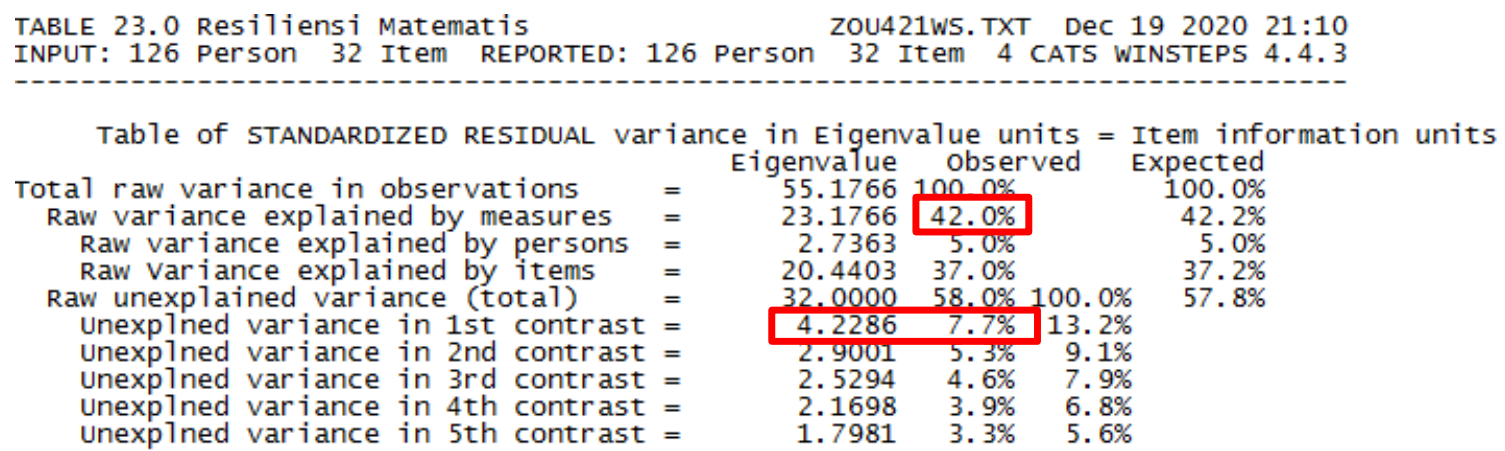

\section{Gambar 2. Output item undimensionality pada Winstep}

Pada Gambar 2., yang perlu diperhatikan adalah kolom raw variance explained by measure dimana skornya adalah $42 \%$ dan kolom unexplened variance in $1^{\text {st }}$ contrast yang skornya eigen value-nya adalah 4.2286 serta skor observednya $7,7 \%$.

Selanjutnya setelah tahapan item undimensionality, dilanjutkan dengan item fit order. Pada tahapan ini, yang perlu diperhatikan untuk analisa adalah nilai Oufit Mean Square (MNSQ), nilai Outfit ZStandard (ZSTD) dan nilai Point Measure Coorelation (Pt Mean Corr). Sebagai contoh pada baris pertama adalah hasil output untuk item nomor 21 pada instrumen resiliensi matematis, berturut-turut skornya dalah 1,70 dan 4,59 serta -0,10. Baris kedua adalah item nomor 9 berturut-turut skornya adalah 1,65 dan 4,61 serta 0,00. Baris ketiga adalah item nomor 22 berturut-turut skornya adalah 1,51 dan 3,63 serta 0,13 dan seterusnya hingga baris ke 32. Secara rinci output item fit order ada pada Gambar 3. 


\begin{tabular}{|c|c|c|c|c|c|c|c|c|c|c|c|c|c|}
\hline \multirow{2}{*}{$\begin{array}{l}\text { Person: } \\
\text { | ENTRY } \\
\text { NUMBER }\end{array}$} & \multicolumn{13}{|c|}{$\begin{array}{l}\text { REAL SEP.: } 1.31 \text { REL.: } .63 \ldots \text { I } \\
\text { ItEm STATISTICS: MISFIT ORDER }\end{array}$} \\
\hline & $\begin{array}{l}\text { TOTAL } \\
\text { SCOREE }\end{array}$ & $\begin{array}{l}\text { TOTAL } \\
\text { COUNT }\end{array}$ & MEASURE & $\begin{array}{l}\text { MODEL } \\
\text { S.E. }\end{array}$ & INNSQ & $\begin{array}{c}\text { NFIT } \\
\text { ZSTI }\end{array}$ & \begin{tabular}{|c|} 
OUT \\
IMNSQ
\end{tabular} & $\begin{array}{c}\text { FIT } \\
\text { ZSTD|C }\end{array}$ & $\begin{array}{l}\text { PTMEAS } \\
\text { CORR. }\end{array}$ & $\begin{array}{l}\text { R-AL } \\
\text { EXP. }\end{array}$ & $\begin{array}{l}\text { EXACT } \\
\text { OBS\% }\end{array}$ & $\begin{array}{r}\text { MATCH } \\
\text { EXP\% }\end{array}$ & Item \\
\hline 21 & 386 & 126 & -.58 & .15 & 1.64 & 4.27 & 1.70 & 4.59 & A-. 10 & .31 & 54.8 & 62.3 & 521 \\
\hline 9 & 406 & 126 & -1.04 & .15 & 1.55 & 3.9 & 1.65 & 4.61 & 00 & .30 & 62.7 & 60.1 & 32 \\
\hline 22 & 323 & 126 & .72 & .14 & 1.50 & 3.58 & 1.51 & 3.64 & C. 13 & .33 & 46.8 & 54.3 & 522 \\
\hline 2 & 371 & 126 & -.25 & .15 & 1.44 & 3.02 & 1.46 & 3.16 & D. .28 & .31 & 61.1 & 62.4 & 52 \\
\hline 19 & 377 & 126 & -.38 & .15 & 1.44 & 3.0 & 1.46 & 3.17 & E .17 & .31 & 56.3 & 62.6 & 519 \\
\hline 12 & 212 & 126 & 2. 81 & .14 & 1.37 & 3.0 & 1.36 & 2.97 & $\mathrm{~F}-.12$ & .32 & 46.0 & 53.3 & 512 \\
\hline 6 & 355 & 126 & .09 & .14 & 1.32 & 2.29 & 1.33 & 2.38 & $G .23$ & .32 & 53.2 & 60.5 & 56 \\
\hline 13 & 246 & 126 & 2.14 & .14 & 1.26 & $2.1 \mathrm{~d}$ & 1.25 & 2.16 & $\mathrm{H}-.06$ & .33 & 61.1 & 54.4 & 513 \\
\hline 30 & 391 & 126 & -.69 & .15 & 1.18 & 1.4 & 1.26 & 1.94 & II .12 & .31 & 63.5 & 62.0 & 530 \\
\hline 20 & 383 & 126 & -.51 & .15 & 1.15 & 1.11 & 1.15 & $1.20 \mid \mathrm{J}$ & ] .40 & .31 & 57.1 & 62.5 & 520 \\
\hline 8 & 369 & 126 & -.21 & .15 & 1.14 & 1.04 & 1.14 & $1.08 \mid \mathrm{K}$ & K. .50 & .31 & 54.0 & 62.1 & 58 \\
\hline 14 & 268 & 126 & 1.74 & .14 & 1.14 & 1.28 & 1.14 & $1.24 \mid \mathrm{L}$ & LL.33 & .34 & 61.1 & 54.3 & 514 \\
\hline $\begin{array}{r}23 \\
4\end{array}$ & 257 & 126 & 1. 94 & .14 & 1.06 & .60 & 1.07 & $.68 \mid \mathrm{N}$ & $M .20$ & .34 & 60.3 & 54.4 & 523 \\
\hline $\begin{array}{r}4 \\
10\end{array}$ & $\begin{array}{l}373 \\
270\end{array}$ & 126 & -.30 & .15 & \begin{tabular}{|l|}
.96 \\
08
\end{tabular} & -.23 & \begin{tabular}{|l|l|}
.98 \\
05
\end{tabular} & -.15 & $N \cdot .56$ & .31 & 57.1 & 62.5 & 54 \\
\hline $\begin{array}{r}10 \\
7\end{array}$ & $\begin{array}{l}229 \\
364\end{array}$ & $\begin{array}{l}126 \\
126\end{array}$ & $\begin{array}{l}2.47 \\
-.10\end{array}$ & $\begin{array}{r}14 \\
15\end{array}$ & \begin{tabular}{|l}
.98 \\
992
\end{tabular} & $\begin{array}{l}-.12 \\
-.61\end{array}$ & $\begin{array}{r}95 \\
93\end{array}$ & $\begin{array}{l}-.39 \\
-.54\end{array}$ & $\begin{array}{l}0.09 \\
P .39\end{array}$ & $\begin{array}{r}.33 \\
32\end{array}$ & $\begin{array}{l}66.7 \\
62.7\end{array}$ & $\begin{array}{l}53.7 \\
61.6\end{array}$ & $\begin{array}{l}510 \\
57\end{array}$ \\
\hline 18 & $\begin{array}{l}304 \\
440\end{array}$ & 126 & -1.88 & .16 & $\begin{array}{l}.92 \\
\end{array}$ & -1.27 & .87 & -1.27 & p. .40 & .28 & 69.0 & 57.9| & 518 \\
\hline 3 & 388 & 126 & -.62 & .15 & 86 & $-1.1=$ & .86 & -1.16 & 0.8 & .31 & 58.7 & 62.2 & 53 \\
\hline 15 & 230 & $\begin{array}{l}126 \\
126\end{array}$ & 2.45 & .14 & .85 & -1.3 & .86 & -1.25 & n. & .33 & 73.0 & 53.8 & 515 \\
\hline 16 & 407 & 126 & -1.06 & .15 & .81 & -1.66 & .82 & -1.58 & m .17 & .30 & 71.4 & 60.0 & 516 \\
\hline 17 & 429 & 126 & -1.60 & .16 & .81 & -1.7 & .81 & -1.85 & 17.42 & .29 & 63.5 & 57.1 & 517 \\
\hline 32 & 397 & 126 & -.83 & .15 & .78 & -1.91 & .77 & -2.01 & $k .63$ & .30 & 63.5 & 61.1 & 532 \\
\hline 2 & 367 & 126 & -.17 & .15 & .77 & -1.9 & .76 & -1.94 & $j .3$ & .31 & 69.0 & 61.9 & 527 \\
\hline 29 & 37 & 126 & -.40 & .15 & .77 & -1.8 & .77 & -1.86 & 10.57 & .31 & 67.5 & 62.6 & 529 \\
\hline 31 & 36 & 126 & -.10 & .15 & .76 & -1.99 & .75 & -2.04 & $h .50$ & .32 & 73.0 & 61.6 & 531 \\
\hline 5 & 36 & 126 & -.06 & .15 & .75 & -2.11 & .75 & -2.05 & $g .51$ & .32 & 67.5 & 61.4 & 55 \\
\hline 1 & 39 & 126 & -.67 & .15 & .68 & -2.82 & .69 & -2.75 & 7.50 & .31 & 69.0 & 62. & s1 \\
\hline 28 & 42 & 126 & -1.42 & .16 & .68 & $-3.1=$ & .69 & -3.09 & e. .53 & .29 & 67.5 & 57. & 528 \\
\hline 26 & 39 & 126 & -.71 & .15 & .68 & -2.87 & .67 & -2.91 & d . 4 & .31 & 69.8 & 61.8 & 526 \\
\hline 25 & 35 & 12 & .19 & .14 & .64 & -3.24 & .64 & -3.19 & c. 4 & .32 & 72.2 & 59. & 525 \\
\hline 1 & 37 & 12 & -.3 & .1 & .59 & -3.78 & .59 & -3.72 & b. & .31 & & 62.5 & 511 \\
\hline 24 & 388 & 126 & -.62 & & & -4.6 & .52 & -4.60 & a .46 & .31 & & 62.2 & 524 \\
\hline $\begin{array}{l}\text { MEAN } \\
\text { P.SD }\end{array}$ & $\begin{array}{r}355.9 \\
60.4\end{array}$ & 126.0 & $\begin{array}{r}.00 \\
1.20\end{array}$ & .15 & 1.00 & $\begin{array}{r}-.21 \\
2.4\end{array}$ & 1.01 & $\begin{array}{r}-.2 \\
2.5\end{array}$ & & & $\begin{array}{r}63.4 \\
7.6\end{array}$ & $\begin{array}{r}59.6 \\
3.3\end{array}$ & \\
\hline
\end{tabular}

Gambar 3. Output Item Fit Order pada Winstep

\section{PEMBAHASAN}

Reliabilitas adalah ketetapan atau keajegan alat tersebut dalam menilai apa yang dinilainya", maksudnya suatu instrumen dikatakan reliabel apabila hasil dari instrumen yang digunakan tersebut, senantiasa akan memberikan hasil yang relatif sama atau bersifat stabil (Sumintono \& Widhiarso, 2015). Uji validitas dan reliabilitas merupakan hal yang esensial yang perlu dipenuhi agar instrumen yang digunakan dalam sebuah penelitian dapat memiliki nilai kepercayaan. Melalui gambar 1 yaitu output Summary Statistics untuk instrumen tes resiliensi matematis mahasiswa calon guru matematika yang ada pada pembahasan Result di atas, akan dicermati beberapa hal sebagai berikut:

1. Person measure, pada output diatas nilai person measure menunjukkan 0.76 , karena nilai tersebut lebih besar dari logit 0,0 . Nilai rata-rata yang lebih besar dari logit menunjukkan kecenderungan abilitas responden yang lebih besar dari pada tingkat kesulitan soal atau responden cenderung mampu merespon pernyataan-pernyataan yang ada pada instrumen.

2. Nilai alpha Cronbach (mengukur reliabilitas yaitu interaksi antara responden dengan item) yang pada output Gambar 1. di atas, nilai alpha Cronbach menunjukkan 0.71. interpretasi skor ini bisa dilihat pada Tabel 2., dengan nilai tersebut maka kriterianya termasuk "Bagus". Sehingga, instrumen yang digunakan dapat dikatakan reliabel. 
Tabel 2. Interpretasi Uji Relialibilitas berdasarkan Nilai Cronbach Alpha

\begin{tabular}{cl}
\hline Nilai & Interpretasi \\
\hline$a>0,8$ & Bagus sekali \\
$0,7<a \leq 0,8$ & Bagus \\
$0,6<a \leq 0,7$ & Cukup \\
$0,5<a \leq 0,6$ & Jelek \\
$a<0,5$ & Buruk \\
\hline
\end{tabular}

(Sumintono \& Widhiarso, 2015)

3. Nilai Person Reliability dan Item Reliability, pada output diatas nilai keduanya menunjukkan 0,63 dan 0.98. Dengan nilai yang ada dari Person Reliability menujukkan bahwa konsistensi jawaban dari responden dikatakan "Lemah", namun untuk nilai Item Reliability menujukkan kriteria nilai yang "Istimewa" sehingga dapat dikatakan kualitas item-item yang digunakan dalam instrumen sangat reliabel.

4. Nilai INFIT MNSQ dan OUTFIT MNSQ, serta INFIT ZSTD dan OUTFIT ZSTD, yang mana keduanya dapat dilihat pada table Person dan Item sebagai berikut INFIT MNSQ nilai personnya 1.01 dan nilai itemnya 1.00, OUTFIT MNSQ nilai personnya 1.01 dan nilai itemnya 1.01, terlihat bahwa Nilai yang ditunjukkan pada tabel person dan item dari INFIT MNSQ dan OUTFIT MNSQ semuanya mendekat kepada nilai 1,00, karena semakin data mendekati nilai 1,00 kualitas dikatakan semakin baik. kemudian untuk INFIT ZSTD nilai personnya -0.44 dan nilai itemnya -0.24, dan INFIT ZSTD nilai personnya 0.45 dan nilai itemnya -0.17 . Melalui nilai-nilai tersebut. Nilai ideal adalah 0,0 dengan artian semakin mendekati nilai ideal maka kualitas semakin baik. Untuk item, semua skor cenderung dekat dengan 0,0, namun untuk person masih jauh artinya data responden penelitian memang ada yang kurang baik dalam menyelesaian instrumen yang diberikan.

5. Pengelompokan person dan item dapat diketahui dari nilai separation. Makin bear nilai separation maka kualitas instrumen dalam hal keseluruhan responden dan butir semakin baik, karena bisa mengidentifikasi kelompok responden dan kelompok item. Untuk separation person skornya pada Gambar 1. adalah 1,61 dan skor separation item adalah 7,63

Berdasarkan tinjauan diatas, maka intrumen kemampuan resiliensi matematis mahasiswa calon guru matematika yang diteliti ini dapat dikatakan sebagai instrumen yang memiliki tingkat reliabilitas yang tinggi dengan rincian sebagai berikut :

Tabel 3. Hasil Pengolahan Uji Reliabilitas

\begin{tabular}{lllllll}
\hline $\begin{array}{l}\text { Cronbach } \\
\text { Alpha }\end{array}$ & $\begin{array}{l}\text { Interpreta } \\
\text { si }\end{array}$ & $\begin{array}{l}\text { Item } \\
\text { Reliability }\end{array}$ & $\begin{array}{l}\text { Interpreta } \\
\text { si }\end{array}$ & $\begin{array}{l}\text { Person } \\
\text { Reliability }\end{array}$ & $\begin{array}{l}\text { Interpret } \\
\text { asi }\end{array}$ & Kesimpulan \\
\hline 0,71 & Bagus & 0,98 & Istimewa & 0,63 & Lemah & Reliabel \\
\hline
\end{tabular}

Berdasarkan Tabel 3. interpretasi Cronbach Alpha adalah 'bagus'. Hal ini menunjukkan bahwa terdapat kesesuaian antara item dan person (responden). Kemudian konsistensi jawaban dari responden (person reliability) dapat dikatakan 'lemah' dengan kualitas butir soal instrument (item reliability) adalah 'istimewa'. Jadi dapat disimpulkan bahwa instrumen kemampuan resiliensi matematis mahasiswa calon guru yang diteliti ini dapat dikatakan reliabel.

Validitas mempermasalahkan seberapa jauh item-item tes mampu mengukur apa-apa yang benarbenar hendak diukur sesuai dengan konsep khusus atau definisi konseptual yang telah ditetapkan (Djaali \& Muljono, 2008). Dalam analisis Rasch, uji validitas di kenal dengan nama item undimensionality (unidimensionalitas instrument) (Sumintono \& Widhiarso, 2015). item undimensionality merupakan ukuran untuk mengevaluasi apakah instrument yang dikembangkan mampu mengukur apa yang seharusnya diukur sehingga dapat dikatakan valid. Analisis Rasch menggunakan analisis komponen utama (principal 
component analysis) dari standardized residual variance (in Eigenvalue units) (Sumintono \& Widhiarso, 2015). Uji validitas berdasarkan item undimensionality dapat terlihat pada nilai raw variance explained by measures. Interpretasi item undimensionality berdasarkan nilai raw variance explained by measures ditunjukkan oleh skor $>20 \%$ dikatakan terpenuhi, $>40 \%$ bagus dan $>60 \%$ untuk kriteria istimewa.

Selain itu untuk mengetahui ada atau tidaknya butir soal yang bermasalah dan tidak cocok, maka dapat dilihat pada nilai eigenvalue dan observed dalam unexplained variance $1^{\text {st }}$ contrast dengan nilai eigenvalue harus kurang dari 3 untuk menunjukkan tidak ada butir soal yang bermasalah dan nilai observed harus kurang dari $15 \%$ untuk menunjukkan butir soal yang sesuai (item fit). Adapun hasil dari pengolahan validitas dengan software Winstep versi 4.4.3 dilihat pada Tabel 4.

Tabel 4. Hasil Pengolahan Validitas Instrumen

\begin{tabular}{|c|c|c|c|c|c|}
\hline \multirow[t]{2}{*}{$\begin{array}{l}\text { Raw variance explained } \\
\text { by measures }\end{array}$} & \multirow[t]{2}{*}{ Interpretasi } & \multicolumn{2}{|c|}{ unexplained } & \multirow{2}{*}{\multicolumn{2}{|c|}{ Interpretasi }} \\
\hline & & Eigenvalue & observed & & \\
\hline $42.0 \%$ & Bagus & 4.2286 & $7.7 \%$ & $\begin{array}{l}\text { Ada item } \\
\text { bermasalah }\end{array}$ & yang \\
\hline
\end{tabular}

Berdasarkan Tabel 4. hasil dari nilai raw variance explained by measures menunjukkan bahwa item tes resiliensi keseluruhsn berada pada kategori "bagus". Selanjutnya, berdasarkan nilai observed pada unexplained variance $1^{\text {st }}$ contrast menunjukkan bahwa tidak ada kecenderungan ketidaksesuaian butir soal sehingga dapat digunakan, namun pada nilai eigenvalue yang lebih dari 3 mengindikasikan ada butir soal yang bermasalah sehingga dapat dilakukan analisis lebih lanjut dengan analisis item fit order untuk menentukan suatu butir soal dapat dipertahankan atau harus diganti.

Item fit atau disebut dengan kesesuaian butir yang mana dapat menjelaskan apakah butir soal berfungsi normal untuk melakukan pengukuran atau tidaknilai outfit means-square, outfit z-standard, dan point measure correlation adalah kriteria yang digunakan untuk melihat tingkat kesesuaian butir (item fit) (Boone et. al., 2014; Bond \& Fox, 2015). Adapun kriteria yang digunakan untuk memeriksa kesesuaian butir soal dapat dilihat pada Tabel 5.

Tabel 5. Nilai Kriteria Kesesuaian Butir Soal

\begin{tabular}{ll}
\hline Kriteria & Nilai \\
\hline Outfit mean square (MNSQ) & $0,5<\mathrm{MNSQ}<1,5$ \\
Outfit Z-standart (ZSTD) & $-2,0<$ ZSTD $<+2,0$ \\
Point Measure Correlation & $0,4<$ PT Measure Corr $<0,85$ \\
\hline
\end{tabular}

Berdasarkan Tabel 5., jika ketiga kriteria terpenuhi pada butir soal maka dapat dikatakan butir soal telah "sesuai" dan dapat dipastikan bahwa kualitas butir soal tersebut bagus dan dapat digunakan, sedangkan jika hanya terdapat dua kriteria atau satu kriteria yang terpenuhi makan butir soal masih dapat dipertahankan dan tidak perlu untuk diubah sehingga dapat dikategorikan "sesuai" dan dapat digunakan, tetapi apabila ketiga kriteria tidak terpenuhi maka dapat dikatakan butir soal tidak sesuai dan dapat dipastikan butir soal "tidak sesuai" sehingga perlu diperbaiki ataupun diganti. Adapun contoh hasil dari pengolahan kesesuaian butir soal dapat dilihat pada Tabel 6. berikut ini yang hanya sampai pada kode penyataan no. 10 pada instrumen. Tabel 6. merupakan hasil yang bisa dilihat dengan berpedoman pada Gambar 3. 
Tabel 6. Hasil Pengolahan Item Fit Order

\begin{tabular}{lllllll}
\hline $\begin{array}{l}\text { Nomor } \\
\text { Soal }\end{array}$ & $\begin{array}{l}\text { Kode } \\
\text { Soal }\end{array}$ & Outfit & & $\begin{array}{l}\text { PT } \\
\text { Measure } \\
\text { Corr. }\end{array}$ & $\begin{array}{l}\text { Status tidak } \\
\text { memenuhi }\end{array}$ & Interpretasi \\
\cline { 3 - 6 } & & MNSQ & ZFTD & 1 Kriteria & Sesuai \\
\hline 1 & P1 & 0,69 & $-2,75$ & 0,50 & 2 Kriteria & Sesuai \\
2 & P2 & 1,46 & 3,16 & 0,28 & - & Sesuai \\
3 & P3 & 0,86 & $-1,16$ & 0,67 & - & Sesuai \\
4 & P4 & 0,98 & $-0,15$ & 0,56 & 1 Kriteria & Sesuai \\
5 & P5 & 0,75 & $-2,05$ & 0,51 & 2 Kriteria & Sesuai \\
6 & P6 & 1,33 & 2,38 & 0,23 & 1 Kriteria & Sesuai \\
7 & P7 & 0,93 & $-0,54$ & 0,39 & - & Sesuai \\
8 & P8 & 1,14 & 1,08 & 0,50 & 3 Kriteria & Tidak Sesuai \\
9 & P9 & 1,65 & 4,61 & 0,00 & 1 Kriteria & Sesuai \\
\hline
\end{tabular}

Tabel 6. menginformasikan mekanisme validasi item yang ada pada instrumen. Diperoleh bahwa item nomor 9 tidak sesuai. Dari mekanisme tersebut dan diterapkan keseluruh item soal yang ada di angket resiliensi matematis mahasiswa calon guru matematika, maka akan diperoleh bahwa item bernomor 9, 21dan 22 merupakan tiga item yang tidak memenuhi tiga syarat kriteria validitas, sehingga dapat dikatakan item tersebut tidak valid (Misfit) dan tidak dapat dipertahankan, melainkan harus dibuang atau diganti. Sedangkan, untuk item lainnya, karena minimal memenuhi satu kriteria untuk dikatakan item fit atau valid, maka nilai item lain yang tidak sesuai dengan kedua kriteria yang ada namun memenuhi satu kriteria tetap dapat dikatakan item Fit atau valid dan masih dapat dipertahankan untuk digunakan pada penelitian, sehingga dari 32 item pada angket, diperoleh 29 butir itemnya yang dinyatakan valid. Secara keseluruhan diperoleh hasil bahwa instrumen kemampuan resiliensi matematis mahasiswa calon guru matematika pada penelitian ini dinyatakan reliabel dan valid dengan kriteria "sangat reliabel" dan 29 dari 32 item pernyataan dikatakan "valid".

\section{SIMPULAN}

Penggunaan model Rasch dalam validasi instrumen akan menghasilkan informasi yang lebih holistik tentang instrumen yang diteliti dan lebih memenuhi definisi pengukuran. Setelah dilakukan analisis data responden terkait instrumen resiliensi matematis calon guru matematika, diperoleh hasil bahwa instrumen kemampuan resiliensi matematis mahasiswa calon guru matematika pada penelitian ini dinyatakan reliabel dan valid dengan kriteria "sangat reliabel" dan 29 dari 32 item pernyataan dikatakan "valid" sehingga untuk meneliti kemampuan resiliensi matematis mahasiswa calon guru matematika bisa menggunakan instrumen ini.

\section{UCAPAN TERIMA KASIH}

Terimakasih peneliti ucapkan kepada Lembaga Penelitian (Lemlit) UHAMKA yang telah mempercayakan kepada tim peneliti untuk memberikan dana agar penelitian ini dapat terlaksana. Terimakasih juga kepada para partisipan yang telah memberikan responnya pada angket reliensi matematis ini. 


\section{DAFTAR RUJUKAN}

Bond, T., \& Fox, C. (2015). Applying the Rasch Model. In Applying the Rasch Model. Routledge. https://doi.org/10.4324/9781315814698

Boone, W. J., Staver, J. R., Yale, M. S., Boone, W. J., Staver, J. R., \& Yale, M. S. (2014). Item Measures. Rasch Analysis in the Human Sciences, 93-110. https://doi.org/10.1007/978-94-007-6857-4_5

Cavanagh, R. F., \& Waugh, R. F. (2011). Applications of Rasch Measurement in Learning Environments Research. Applications of Rasch Measurement in Learning Environments Research. https://doi.org/10.1007/978-94-6091-493-5

Djaali, \& Muljono, P. (2008). Pengukuran dalam bidang pendidikan. Jakarta: PT.GRASINDO.

Hendriana, H., Soemarmo, U., \& Rohaeti, E. E. (2017). Hard Skill dan Soft Skil. Refika Aditama (1).

Hutauruk, A. J. B. (2020). Indikator Pembentuk Resiliensi Matematis Mahasiswa Prodi Pendidikan Matematika FKIP. Sepren, 1(02), 78-91. https://doi.org/10.36655/sepren.v1i02.227

Johnston-Wilder, S, Lee, C., Brindley, J., \& Garton, E. (2015). Developing Mathematical Resilience in School-Students Who Have Experienced Repeated Failure. Iceri2015: 8Th International Conference of Education, Research and Innovation.

Johnston-Wilder, S, Lee, C., Brindley, J., \& Garton, E. (2015). Developing Peer Coaching for Mathematical Resilience in Post-16 Students Who Are Encountering Mathematics in Other Subjects. Iceri2015: 8Th International Conference of Education, Research and Innovation, 6002-6011.

Johnston-Wilder, Sue. (2013). Measuring mathematical resilience: an application of the construct of resilience to the study of mathematics. AERA 2013, San Ffancisco California, University of Warwick, 1-15. http://wrap.warwick.ac.uk/51559

Kemdikbud. (2016). Standar Kompetensi Lulusan Pendidikan Dasar dan Menengah. Lampiran Peraturan Menteri Pendidikan dan Kebudayaan Republik Indonesia Nomor 20 Tahun 2016.

Misbach, I. H., \& Sumintono, B. (2014). Pengembangan dan Validasi Instrumen "Persepsi Siswa Tehadap Karakter Moral Guru" di Indonesia dengan Model Rasch. PROCEEDING Seminar Nasional Psikometri, 148-162.

Muntazhimah, M. (2019). Pengembangan Instrumen Kemampuan Berpikir Reflektif Matematis siswa Kelas 8 SMP. Imajiner: Jurnal Matematika Dan Pendidikan Matematika, 1(5), 237. https://doi.org/10.26877/imajiner.v1i5.4551

Sappaile, I. B. (2007). Konsep Instrumen Penelitian Pendidikan. Jurnal Pendidikan dan Kebudayaan.

Sumintono, Bambang \& Widhiarso, W. (2015). Aplikasi Pemodelan Rasch pada Asesmen Pendidikan, 1127.

Sumintono, B. (2016). Penilaian Keterampilan Berpikir Tingkat Tinggi : Aplikasi Pemodelan Rasch pada Asesmen Pendidikan. Seminar Nasional Pendidikan IPA, FKIP Jurusan PMIPA, Universitas Lambung Mangkurat.

Sumintono, B., \& Widhiarso, W. (2013). Aplikasi Pemodelan Rasch Pada Assessment Pendidikan [Applications of Rasch Modeling in Educational Assessments]. Aplikasi Permodelan Rasch Pada Assesment Pendidikan (Issue September).

Wibisono, S. (2018). Aplikasi Model Rasch Untuk Validasi Instrumen Pengukuran Fundamentalisme Agama Bagi Responden Muslim. Jurnal Pengukuran Psikologi Dan Pendidikan Indonesia (JP3I), 5(1). https://doi.org/10.15408/jp3i.v5i1.9239

Xolocotzin, U. (2017). Understanding Emotions in Mathematical Thinking and Learning. In Understanding Emotions in Mathematical Thinking and Learning. https://doi.org/10.1016/C2014-0-02036-9 